\title{
Provocation as a Complete Defence to Trespass to the Person
}

\section{ANDREW PINGREE*}

The basis on which the law of trespass to the person denies mitigation of compensatory damages is a purely philosophical position which can be described as high minded but impractical. The law is criticised in this article on a number of bases including the fact that the leading case, Fontin $\mathrm{v}$ Katapodis, established this position without revealing the judicial reasoning which was applied. The notion of a victim's fundamental right not to be touched or threatened is criticised and an argument of implied consent by the provocateur is put, as also is an argument that a person's actions can be so much a function of external influences that their blame ought to be reduced proportionally. Some policy considerations are also raised to justify a change in the law.

\section{INTRODUCTION}

It is well established law in Australia that the award of exemplary damages can be mitigated or denied if the plaintiff provoked the assault or battery that he or she complains of. That makes provocation a partial defence. This article puts the case that provocation may be arguable as a defence to an action and as grounds for mitigation or elimination of compensatory damages too. Because both assault and battery are trespasses, and because the complete defences of consent, necessity, self defence, defence of property, and the retaking of goods apply equally to both, the two actions will be discussed together in this article. Some of the sources cited herein refer to provocation as a subset of the pleading of contributory negligence (which is based on statute law in non-Australian jurisdictions). Provocation is not approached that way here, but rather as a common law defence in its own right.

It is necessary, in order to commence a discussion of provocation, to define it clearly. Unfortunately, in Australian tort law it is difficult to find a clearly articulated definition of provocation. But thanks to judicial treatment of the

\footnotetext{
* BA(Hons) in Sociology (Deakin University), JD student, Monash University.
} 
Contributory Negligence Act of Alberta (Canada) ${ }^{1}$, there is such a definition in Canadian common law. Slatter J, in Wilson v Bobbie, stated that:

Provocation is defined as conduct that would cause a reasonable person to lose self control ... To be recognised by the law, the provocation must occur in close proximity to the assault ... It might amount to no more than taunting, insults or annoyance, in which case it is neither a tort nor a crime ... On the other hand, provocation may arise from [a criminal] assault, a trespass, or some other conduct that is a tort or crime, or both. ${ }^{2}$

This is quite similar to the definition in British and Australian criminal law. For example, in Mancini v Director of Public ProsecutionsViscount Simon LC said:

It is not all provocation that will reduce the crime of murder to manslaughter. Provocation, to have that result, must be such as temporarily deprives the person provoked of the power of self control, as the result of which he commits the unlawful act which causes death...

The test to be applied is that of the effect of the provocation on a reasonable man, as was laid down by the Court of Criminal Appeal in Lesbini $[R v$ Lesbini [1914] 3 KB 1116] ... so that an unusually excitable or pugnacious individual is not entitled to rely on provocation which would not have led an ordinary person to act as he did. In applying the test, it is of particular importance (a) to consider whether a sufficient interval has elapsed since the provocation to allow a reasonable man time to cool ... ${ }^{3}$

Provocation in homicide is judged both according to the subjective standard of whether the defendant was indeed provoked, and the objective standard of whether the situation would provoke a reasonable person. One must keep two points in mind, however. Firstly, in criminal proceedings for charges less than homicide (that is, those equivalent to common battery and assault) provocation can be taken into account only in sentencing. The sentence is equivalent to the calculation of damages at tort, which means that the criminal law model suggests maintaining provocation only as a partial defence. Secondly, according to the court in $R v$ Kirkham $^{4}$ and then the treatment of that judgment in $R \vee$ Smith $^{5}$ the criminal concept of provocation is one of

\footnotetext{
${ }^{1}$ RSA 2000 Ch C-27

2 (2006) ABQB 22, [17], applying Hurley v Moore (1993) 107 DLR $\left(4^{\text {th }}\right) 664$ (Newfoundland Court of Appeal).

${ }^{3}$ [1942] AC 1, 9.

${ }^{4}$ (1837) 8 C\&P 115, 117; 173 ER 422.

${ }^{5} R v$ Smith [2001] 1 AC 146.
} 
compassion for human frailty, and not a scaling of the charge according to what the defendant meant by his or her actions. The criminal concept of provocation was of special value when the penalty for murder was death. Therefore it assists us only in establishing a definition and test, whereas we seek here to apply the definition and test to situations to which the criminal law does not apply them. But, in spite of these issues, the adoption of the criminal definition at Canadian tort law provides a solid basis on which to proceed.

\section{Established LAW}

The leading case with respect to battery in Australian law, albeit not the original case, is Fontin $v$ Katapodis. ${ }^{6}$ As it was decided by the High Court, all lower courts are bound to follow it unless distinctions can be found, or unless the High Court itself finds fault with and overrules it. During an altercation, the defendant, a glass cutter, threw a piece of glass at the plaintiff in response to the plaintiff having first struck the defendant with a T-square. (The defendant was accused by the plaintiff of having stolen something on a previous visit to the plaintiff's workplace). Both Owen J and McTiernan J recognised independently that prior authorities show exemplary damages to be disallowed where provocation is proven. Prima facie, then, provocation is a partial defence to battery. But provocation was ruled to be irrelevant in relation to the plaintiff's entitlement to compensation; thus, a plaintiff must receive full compensation regardless of how much he/she has pushed the defendant into lashing out. Fontin is generally referred to as authority for this rule, for example in Lane $v$ Holloway, ${ }^{7}$ which is authority for the same principle in the United Kingdom. As for assault, by nature it is a lesser tort than whatever battery it may purport to precede, so it is not unreasonable to expect a court to behave with at least similar clemency in the case of a provoked assault.

Just as there are varying degrees of assault and battery, attracting varying sums in damages, there are also varying degrees of provocation. In spite of this $t$ he law in Australia is somewhat harsh towards the Defendant in that any provocation, whether small or great, is disregarded by courts to the same effect. In Whitfield $v$ De Lauret \& Co $L t d^{8}$ Knox CJ stated: 'Damages may be either compensatory or exemplary ... Exemplary damages are given only in cases of conscious wrongdoing in contumelious disregard of another's rights.'

\footnotetext{
${ }^{6}$ (1962) 108 CLR 177.

${ }^{7}$ [1968] 1 QB 379. The ruling in this case was based on Fontin, above $n 6$.

${ }^{8}$ (1920) 29 CLR 71.
} 
The dictionary definition of 'contumelious' shows that it is by no means a strong word. Describing an 'insulting display of contempt in words or actions; contemptuous or humiliating treatment, ${ }^{9}$ it catches any offensive physical act done in anger, whether provoked or unprovoked; whether extreme or moderate.

It is worth considering cases where the provocation and the response to it are of varied intensities and are balanced in different ways. In Murphy v Culhane, the balance of the facts was, as Lord Denning MR observed, more favourable to the defendant. His Lordship considered that the pleading should have been one of self defence and not provocation, in which case the defendant would have succeeded. ${ }^{10}$ In his brief ratio he commented on Lane and on Fontin, where:

the conduct of the injured man was trivial - and the conduct of the defendant was savage - entirely out of proportion to the occasion. So much so that the defendant could fairly be regarded as solely responsible for the damage done. I do not think [exemplary damages] ... can or should be applied where the injured man, by his own conduct, can fairly be regarded as partly responsible for the damage he suffered. ${ }^{11}$

Lord Denning went on to approve that damages per se should either be mitigated or aggravated according to the circumstances of the case. In so doing he reiterated his earlier ratio in Gray $v$ Barr $^{12}$ where he mentioned a variety of factors that a jury might wish to take into account in tailoring the sum of compensation. Blay has represented this as authority for the mitigation of compensatory damages in the context of provocation. ${ }^{13}$ But Lord Denning went on to say in Gray that, 'In their [the bereaved party's] claim, all questions of the provocation to Mr Barr and the conduct of Mr Gray are irrelevant. ${ }^{14}$ It is possible then that, rather than vaguely suggesting that the law should take an appropriate opportunity to change for the better, when his Honour referred to tailoring the sum of compensation, he may simply have been loose with terminology.

\footnotetext{
${ }^{9}$ Random House Dictionary, Random House, 2010.

${ }^{10}$ Murphy v Culhane [1977] QB 94, 97

${ }^{11}$ Murphy v Culhane [1977] QB 94, 98.

${ }^{12}$ [1971] 2 QB 554.

${ }^{13}$ S K N Blay, Provocation in Tort Liability. A Time for Re-assessment (1988) 4 Queensland University of Technology Law Journal 151, 158.

${ }^{14}$ Gray v Barr [1971] 2 QB 554.
} 
Blay has also argued that the ruling in Fontin that provocation cannot mitigate compensatory damages is not based on solid grounds. ${ }^{15}$ Explaining this, he referred to Owen J having said that contemporary editions of Halsbury's Laws of England ${ }^{16}$ and Sedgwick on Damages ${ }^{17}$ both recognised provocation as a partial defence to mitigate exemplary damages, but neither recognised provocation as a basis to mitigate compensation. Blay notes that neither source in fact makes any assertion on compensation, instead leaving the question very much alone. Owen J's interpretation, therefore, seems regrettably exegetical. McTiernan J cited 15 cases and texts that apparently held differing views to demonstrate the controversy over whether provocation can mitigate compensatory damages. He then announced that he held 'the view that there ought to be no reduction of actual or compensatory damages for provocation in the case of assault and battery'. ${ }^{18}$ His Honour did not explain the logic of that view. ${ }^{19}$ Thus the court bound Australian law to a position based neither on logical reasoning nor on precedent and that was not supported by a policy position. Therefore, the authority of Fontin is not flawless.

\section{A A Possible Precedent for Mitigation of Compensation?}

While all well known authorities stand firmly against mitigation of compensation, one rarely-cited New Zealand case stands in favour of it in special circumstances. Moller $\mathrm{J}$ in Hoebergen $v$ Koppens ${ }^{20}$ recognised the authority of Lane that compensation is not to be mitigated. But he distinguished the facts of the case on the basis of the apparently great likelihood of a battery resulting from the insult that was uttered. As explained by Hudson:

[I]n Hoebergen's case the respondent plaintiff was well aware of previous hostility which had so nearly resulted in violence that he had to flee and had every reason to suppose that any insult from him would 'almost inevitably' result in violence. Moreover at the meeting which occasioned the battery the respondent could easily have walked away but he chose to stay and uttered the insult which brought on the attack. In short Moller $\mathrm{J}$ seemed to regard the coupling of verbal provocation with remaining in close proximity to the

\footnotetext{
${ }^{15}$ Blay, above n 13, 153.

${ }^{16}$ Halsbury's Laws of England vol 11 (Butterworths, $3^{\text {rd }}$ ed, 1952-1964) 225.

${ }^{17}$ Sedgwick on Damages (8 ${ }^{\text {th }}$ edition, 1891) 384.

${ }^{18}$ Fontin v Katapodis (1962) 108 CLR 177, 180.

${ }^{19}$ Noted by Blay, above n 13, 153.

${ }^{20}$ [1974] 2 NZLR 597.
} 
defendant when violence was 'almost inevitable', despite the fact that there was an easy means of escape, as contributory negligence going in reduction of compensatory damages. ${ }^{21}$

Provocation as a form of contributory negligence has been ruled out by various authorities ${ }^{22}$ on the basis of statutory definitions. In Dellabarca $v$ Northern Storemen and Packers Union, while Moller J's interpretation of the statutory definition of 'fault' was discarded, his allowance of an exception due to the inevitability of the trespass, given the provocation, was retained. ${ }^{23}$ In the course of the present study no case has been found to overrule the point of interest here. But Hudson gives a worthwhile warning against taking Hoebergen as good law. Significantly, Moller J did not refer to the many existing authorities against mitigating compensatory damages for provocation. Hudson refers to a passage of Brooking J's judgment in Horkin and the many cases and works cited therein. ${ }^{24}$ Brooking J put the law very firmly, stating at one point, 'Clearly provocation is no defence to an action for battery. This is implicit in the decisions on whether provocation goes in mitigation of damages, and at times is made explicit in such decisions ... ${ }^{25}$ Hudson regards Brooking J's study of the authorities as exhaustive and notes that the position reached concurs also with American authority. ${ }^{26}$

\section{B Fundamental Rights of the Victim}

It is a common argument for allowing nominal damages and full compensatory damages regardless of circumstances, that all people have a right not to have their physical wellbeing threatened or their person violated, even slightly. It might be said that, as provocation can serve to eliminate or mitigate exemplary damages, regardless of how slight or shocking the response is, it follows that, by provoking a trespass, the provocateur has in fact reduced his or her right not to be violated or threatened. However, while compensatory damages are about the rights of the plaintiff, exemplary damages (or punitive or aggravated damages) are about imposing punishment beyond mere compensation so as to teach the defendant a lesson. The rule of

\footnotetext{
${ }^{21}$ A H Hudson, Contributory Negligence as a Defence to Battery (1984) 4:3 Legal Studies 332, 336.

${ }^{22}$ See Horkin v North Melbourne Football Club [1983] 1 VR 153 and Dellabarca v Northern Storemen and Packers Union [1989] 2 NZLR 734 as examples.

${ }^{23}$ [1989] 2 NZLR 734, 798-99.

${ }^{24}$ Horkin v North Melbourne Football Club [1983] 1 VR 153, 159-162.

${ }^{25}$ Ibid 162.

${ }^{26}$ Hudson, above n 21, 338.
} 
the plaintiff's fundamental right may be seen to persist in combination with the additional amount awarded as punishment of the defendant.

In Hill $v$ Cooke ${ }^{27}$ the damages at issue were nominal damages awarded for two slaps in the face. The damages remained payable in spite of provocation, as a recognition of the plaintiff's right to have some sort of remedy for violation of his basic right not to be touched in a way that was uninvited. McTiernan J stated in Fontin:

[T]he law provides a remedy for any damage or loss occasioned by a wrongful act and, therefore, if provocation brings the defendant to do any act in excess of lawful self-defence which results in personal injury and economic loss to the plaintiff, he is entitled to just and adequate damages, and to mitigate or reduce actual or compensatory damages is to deprive the plaintiff pro tanto of a legal right.

Owen J reached the same conclusion. McTiernan J went on: 'This would seem to place actual or compensatory damages for assault and battery on the same footing as damages for personal injury caused by negligence.' In essence this means that provocation reduces the fault element behind the attack, and that awarding a remedy nonetheless is justified by the award of an equal remedy for harm caused not purposefully but negligently. If provocation makes an otherwise intentional trespass less intentional and more negligent, then a suit in negligence is an option available to the plaintiff along with negligent trespass. ${ }^{28}$ By? pleading negligence, the plaintiff may permit his or her own actions to mitigate the damages, and such actions logically would include provoking the defendant. The question then arises, why should the one act be treated two different ways by the one justice system, where both causes can succeed? An answer may lie in the fact that, when suing in trespass, the plaintiff is saying, 'My fundamental human right not to be violated or threatened was breached,' whereas suing in negligence, he or she is saying, 'I suffered harm due to something the defendant did or failed to do.' In negligence there is no reference to a fundamental right and so the plaintiff does not bring that concept into the action at court.

But clearly, on the basis of cases such as Hill, the sum awardable in recognition of that fundamental right is very small. It does not logically follow from the light-handed treatment of this right, where it is violated without any injury, that, when there is an injury, full compensation is owing regardless of where the balance of fault lies between plaintiff and defendant.

\footnotetext{
${ }^{27}$ Hill v Cooke (1958) 58 SR (NSW) 49.

${ }^{28}$ As an example of a negligent trespass, see Williams v Milotin (1957) 97 CLR 465.
} 
The law of trespass fails to recognise the effort and determination, or lack thereof, that goes into both the trespass and the provocative act that preceded it. It may be said that where intense provocation is followed by a slight trespass, the law delivers injustice by imposing a penalty against the trespassor. The position of negligence law is more plausible than this. The cases of Andary v Burford and Wagstaff $v$ Haslam $^{29}$ show that the plaintiff's provocation of the defendant's injurious act is equivalent to contributory negligence. Contributory negligence is used to mitigate compensatory damages in a negligence suit. Although a mitigation in compensation for contributory negligence may be taken as meaning that the plaintiff's right not to be violated can be devalued, it can equally be said that the mitigation is not a finding of fault against the plaintiff for their contributing act and motive and manner of execution, but rather only a softening of the remedy according to their contribution to their own harm. The damages owing in the end are calculated by subtracting a sum representing the plaintiff's degree of fault from what the plaintiff would otherwise deserve. Taken that way, a reduction in compensation for trespass does not militate at all against the concept of a fundamental right, but only serves to soften the response of the law to the violation of it.

Blay has also argued that Owen $\mathrm{J}$ in Hill implicitly recognised that provocation can mitigate damages when he stated that the jury was entitled to award nominal damages for the provoked attack. However, the battery in question did not occasion injury; therefore the harm was not assessable. As in other fields of law, nominal damages are there as a recognition of the plaintiff's right per se to a remedy, even when no recognisable harm has been suffered. Nominal damages are not a reduced form of compensation. (On this point see Blay's own writings elsewhere). ${ }^{30}$

\section{Implied Consent}

An argument exists that provocateurs implicitly consent to the trespass they have provoked. As observed by Hudson:

Prosser on Torts says that 'if the plaintiff voluntarily places himself in the way of attack, his conduct may amount to consent and bar recovery.' Professor Glanville Williams takes the same view, saying that the defence

\footnotetext{
${ }^{29}$ Andary v Burford (1994) Aust Torts Reports 81-302 and in Wagstaff $v$ Haslam [2006] NSWSC 294 (21 April 2006).

${ }^{30}$ Sam Blay, Torts (Lawbook, 4th ed, 1999). Online excerpt at <www.findlawaustralia.com.au $>$.
} 
might be expressed in terms of consent or causation, the precise name not mattering. ${ }^{31}$

To think of provocation as a cause of a tort conjures up a picture of a person being provoked to the point of automatism so that their own will is no longer in play. On the other hand, provocation as evidence of consent and not causation implies a lesser form of provocation that puts the defendant in a state of outrage, but not automatism. If the plaintiff's conduct is such as would quite clearly result in a reasonable person retaliating tortiously, then the plaintiff cannot succeed in arguing the lack of any awareness at all that he or she was consenting to a tortious response. It can be said that the concept of placing oneself in the way of harm is somewhat more relevant for the person who dashes onto a busy road to rescue a child than for someone who puts another's temper and resolve to the test with ridicule or a challenge to a fight. The basis of the difference should be simply the obviousness with which the danger should appear to a reasonable person in the plaintiff's position. A form of provocation calculated to hurt and aimed at a person known for violence and vindictiveness, and whose physical prowess or socioeconomic power is sufficient to leave him or her with nothing to lose (apart from court action) in committing a trespasswould evince consent (or establish causation) much more than a mild throwaway line uttered to a person who may encounter difficulty by retaliating. Such a law unfortunately favours those who are dangerous and/or powerful, but the logic behind it ought not be ignored. This problem is a clear sign that any alteration to the law must cater for David and Goliath situations. No Goliath should be permitted to rely on his reputation or intimidating presence to avoid compensating a David, regardless of whether the David was moved by valour, naivety, or base aggression. For that reason an argument of implied consent should not be allowed in so much as it is based on inequality between the parties.

The case of Zinck $v$ Strickland ${ }^{32}$ indicates a relationship in Canadian law between provocation and implied consent to battery. ${ }^{33}$ In that case the deceased, Mr Zinck, challenged Strickland to a fight in front of a tavern while holding a wooden beam. The co-defendant, Mr Brake, was a drunken patron who was apparently incensed at witnessing the challenge, and he stepped in to fight Zinck instead. Zinck eventually died of head injuries and his dependent mother sued. The court found that Zinck had implicitly consented to the

\footnotetext{
${ }^{31}$ Hudson, above n 21, 332-3. Citing Prosser on Torts: edition and page reference not given.

${ }^{32}$ Zinck $v$ Strickland (1981) NSR (2d) 451. Brake was the second defendant. The fact that he was never challenged to a fight and only stepped in of his own accord was not considered.

${ }^{33}$ As expressed in footnotes by Blay, above n 13, 155.
} 
violent acts of Brake by having sought to engage in violence himself. In citing this case Blay has written:

By its very nature an act which is induced or provoked by the deliberate conduct of the plaintiff can hardly be classified as wrongful. If the plaintiff provokes a given conduct he in effect invites it; he thus implicitly consents to that interference with his rights. The action of the defendant in such cases cannot be deemed wrongful because as the maxim goes, "no harm is done to him who consents." 34

In Gordon v Levi ${ }^{35}$ the Court declined, on the basis of preceding authorities, to strike a balance between the fault of the provoked defendant and of the provocateur plaintiff. The only exceptions allowed were where volenti non fit injuria and ex turpi causa non oritur actio apply. It was stated in obiter dicta in Gordon that:

for conduct to amount to fault contributing to the injury sustained, it must have a direct physical connection with the trespass concerned ("contributing fault”). It is not sufficient if the provocation derives merely from the contextual background. ${ }^{36}$

It was commented in Wilson that this 'implies that the victim of a crime does not contribute to his or her own damage'. ${ }^{37}$ (Such a position is validated on policy grounds by comments his Honour made earlier about violent situations where a finding of contribution by the victim of a crime would be undesirable). But there are problems with this position, as a 'direct physical connection' is impossible where assault rather than battery is concerned, and where the provocation is either verbal or implicit. If the defence of provocation is put totally out of reach in an action for assault, this would have the effect of making it a more serious offence than battery. This suggests that either the Canadian authorities or the appraisals of them are inadequate. It is perhaps better to suggest that the allowance of the defence of provocation where the defences of volenti and ex turpi apply, implies an allowance for provocation of such a serious nature that retaliation is virtually a certainty, or that retaliation is, in the sense of basic moral justice, perfectly reasonable. This does not necessarily restrict the scope of what is defensible to the realm of automatism. There is quite probably room to defend trespasses based on an intense - but predicable and reasonable — wish to defend the dignity of oneself or of another.

\footnotetext{
${ }^{34}$ Blay, above n 13, 155.

35 [1993] EWJ 693 (CA).

${ }^{36}$ Gordon v Levi [1993] EWJ 693 (CA) [51].

${ }^{37}$ Wilson v Bobbie (2006) ABQB 22, [23].
} 


\section{Causation and the Will}

The possibility of automatism was raised above in passing. We now turn to discuss that issue in depth. The Court in the classic case of Scott $v$ Shepherd ${ }^{38}$ traced the causation of the act which caused the plaintiff's injury back, through a series of acts by different persons, to the defendant who had committed the initial, intentional act. A lit firecracker was thrown by the Defendant into a crowded market. The person who was first to be struck by it panicked and threw it away, whereupon it struck another person in the market, then another, and it finally exploded in a patron's face causing blindness. Although each actor in the situation who encountered the 'lighted squib' had an option as to where to throw it, and although the last actor had an option of not throwing it at the plaintiff, the court ruled that each actor was acting not of his own free will, but in a panic resulting from the previous action. Implicitly, then, the act of the first person in the causal chain continued as the cause of each subsequent act, as if the subsequent actors were in a state of automatism. Meir Dan-Cohen has written a lengthy paper ${ }^{39}$ presenting a metaphysical argument on how the boundaries of the self extend into one's social world due to the impact that the social world has on the mind. Considering provocation at tort, he has argued that defendants act not entirely of their own inner volition, but in reaction to external factors. ${ }^{40}$ One may say that when a person's action is contributed to, at least in great part, by another person's act of free will, then the will of the other person is carried through into the first person's action, absolving the first person of some, or potentially all, blame. On this reasoning, when provocation is relevant, it would have the same effect as the defence of automatism in criminal law. ${ }^{41}$

Scott is not used as authority for provocation. The principal distinction is that the factor that evoked each successive act had nothing to do with the plaintiff, but rather the defendant. The causal chain in Scott, then, was the reverse of that which is to be expected in a case where provocation is relevant. But the response of each person was defensive and automatic, typical of torts that follow intense provocation, but just not directed at the provocateur. If one considers the well known 'fight or flight' response, in Scott it was flight (after a fashion) rather than fight, that took effect, but both are variant reactions under the one state of mind - that being panic of sufficient intensity to lead to automatism. It is arguable, then, that the law of trespass gives sufficient

\footnotetext{
${ }^{38}$ Scott v Shepherd (1773) 2 Wm Bl 892.

${ }^{39}$ Meir Dan-Cohen, 'Responsibility and the Boundaries of the Self' (1992) 105:5 Harvard Law Review 959.

${ }^{40}$ Ibid 965.

${ }^{41}$ Ibid 990.
} 
recognition to automatism to allow its application in situations where the response is not to flee but to retaliate. This argument points clearly towards making provocation both a complete defence and a basis for mitigation of damages, due to the potential for different degrees of provocation and different levels of free will inherent in an individual act. The exact nature and extent of the operation of the defence should depend on how much free will appears to have been engaged in the defendant's actions. The severity of the provocation in terms of its likely effect on a reasonable person, together with the reasonableness of the defendant's response, should both be considered.

\section{E Likeness to Criminal Law}

In State Rail Authority of New South Wales $v$ Wiegold it was stated that if, in a suit at tort, a tortfeasor were exonerated of an act that he had already been found guilty of in a criminal trial, it 'would generate the sort of clash between civil and criminal law that is apt to bring the law into disrepute'. ${ }^{42}$ The defendant cannot be found both guilty and innocent in any sensible system, unless the difference results purely from procedural technicalities. ${ }^{43}$ This is a very good reason to maintain consistency between tort and criminal fields of laws. (Crimes are of such a nature that the assignment of moral culpability ought not to be compromised, unlike the case in civil matters where liability is strict). The judgment in Wilson turns on this point and assigns full responsibility for torts amounting to crimes to the tortfeasor. Slatter J proposed a number of crime situations in which the transfer of responsibility from victim to perpetrator would be most inappropriate:

If the plaintiff breaks into the tortfeasor's house, and the tortfeasor beats him beyond what is reasonably necessary for defence of self or of property, can the tortfeasor claim that the plaintiff has contributed to his own injuries? If a motorist changes lanes unsafely, so as to commit ... [a traffic] offence ... and at the next stop light the tortfeasor beats him in a fit of road rage, can the tortfeasor claim that the plaintiff has contributed to his own injuries? If a wife insults and enrages her husband, and he hits her, can he argue that she brought the beating on herself? If a husband finds his wife with another man, is he justified in beating his wife or her lover? Is the damage or loss "caused" by the precipitating conduct of the plaintiff? This raises issues of causation and policy. ${ }^{44}$

\footnotetext{
42 (1991) 25 NSWLR 500, 514 (Samuels JA).

${ }^{43}$ Ibid.

${ }^{44}$ Wilson v Bobbie (2006) ABQB 22, [18].
} 
Outcomes like these would limit any court's willingness to change the law in the way considered here. But Slatter J seems to have conceived of the assignment of blame as an all-or-nothing proposition. Yet one need not assume that the sharing of blame need result in anything remotely like that. A victim of a tort might be found just one per cent to blame, or indeed 99 per cent to blame. ${ }^{45}$ All that is needed is a rule that, to whatever extent the tort was the defendant's fault, the defendant must pay, and to whatever extent it was the plaintiff's fault, the plaintiff must bear it. Unless a civil court mitigated damages by 100 per cent, or unless, in a particular case, heavy mitigation undermined the notion of criminal intent, the civil court would technically not be in disagreement with the criminal court. Moreover, when a criminal court hands down a suspended or heavily mitigated sentence for a serious crime, this is often done in order to recognise that the defendant was not entirely to blame; the shifting of blame at tort toward a provocateur plaintiff has the same function. The adjustment of a sentence is analogous to the adjustment of the total sum of damages, whether compensatory or otherwise.

One may reasonably expect the High Court to prefer to keep the criminal and tort law treatment of provocation in symmetry. If one were to achieve a wider effect for provocation in tort law, one might also have to ask the High Court to widen the effect of provocation at criminal law equivalently. It would take an overwhelming argument to achieve this. It also seems unlikely that the High Court would change the law as argued here when Parliament can intervene in a much more elegant fashion. It would therefore be difficult to get the existing authority of Fontin overruled, but the preceding arguments do appear to carry substantial weight, so it may not be impossible. Nevertheless statutory law reform may be a more likely resolution to the problems raised here.

However, whether it is even desirable to maintain a likeness between tort and criminal approaches to the fault element in an act of provocation must be considered in the light of whether the two bodies of law treat the fault the same way. If they treat it differently then it is plausible that differing outcomes for the same set of facts are to be understood in exactly the same way as would be the case where a contravention of civil law is sued upon at contract, tort and equity, resulting in divergent outcomes.

\footnotetext{
${ }^{45}$ Wrongs Act 1958 (Vic) s 26(1)(b) requires a court when considering a plaintiff's contributory negligence to torts generally to adjust damages downward to an appropriate extent. Section 63 allows damages for an action in negligence to be reduced by up to 100 per cent.
} 
The test to be looked at here is whether, in tort law, mitigation of exemplary damages is a reaction to the plaintiff's wrongdoing or to the defendant's reduced fault, or both. Slatter J in Wilson observed that there is neither a tort nor a crime of provocation, ${ }^{46}$ which suggests that the law would not regard provocation as a wrongdoing that needs a judicial response. That puts emphasis on the defendant's state of mind. Furthermore, in the criminal case of Kirkham, ${ }^{47}$ it was said that provocation commutes a criminal charge of murder to manslaughter due to society's compassion for the defendant's human frailty, and not in recognition of any reduced fault on the defendant's part. It is significant that this rule came into being when the death penalty still existed, making it highly undesirable that a provoked murder should be treated the same way as one originating entirely from the defendant's free choice. On this very superficial examination, the criminal concept and the tort concept then appear to be quite alien to each other, which might encourage a divergence in the law in spite of the apparent disparities that would be created.?? But there is little ground presented here on which to establish such a distinction and further study is warranted.

\section{Policy Arguments Regarding Law Reform}

\section{A Bullying}

A person can be provoked in small ways that would not necessarily prompt a reasonable person to engage in, or threaten, violence. An example might be the use of a nickname such as 'fatso' or 'stupid'. Even if such provocation were repeated occasionally, there may be an expectation that a reasonable person would allow it and ignore it. But, when subjected toimportunate repetition of such names in a spirit of derision or ridicule - such that it amounts to bullying - a reasonable person would become enraged so that threats and attacks in response are to be expected. The law as it stands supposes that it is a better outcome that bullying should continue rather than that the victim should turn the tables with a decisive self-help remedy. It is well known that prolonged bullying, especially for children, can have a profound effect on self esteem and social adjustment, and can even lead to psychiatric harm. By the time a recognised psychiatric condition has emerged, on which a victim can sue in negligence, ${ }^{48}$ it is likely to be far too late. But for the law to be ameliorated adequately, the current requirement of immediacy or

\footnotetext{
${ }^{46}$ Wilson v Bobbie (2006) ABQB 22, [25].

${ }^{47}$ Kirkham, above n4. See also discussion of Kirkham in Smith, above n 6.

${ }^{48}$ As required by statutes such as the Wrongs Act 1958 (Vic) s 72(1).
} 
directness (as in Gordon) needs to be liberalised in like manner as the criminal law has been to deal with domestic homicides following learned helplessness.

Provocation could be constituted by physical contact of an annoying or generally threatening nature. ${ }^{49}$ As the law stands, if the provocative behaviour were quickly to become more and more extreme so as to pose a credible threat, the defendant, responding violently, could argue self defence and avoid damages altogether. In the absence of a fully fledged defence of provocation, should a defendant retaliate maybe seconds before the threat arises (perhaps pre-emptively on a disputable assumption of attack), the defendant would have to pay damages for any resulting injuries. (The author of this article has personally observed incidents in which intending attackers purposefully pose a growing threat in order to build disabling fear in their intended victim, so that a threatening response early on is the only practical defence to prevent a real attack from taking place). Without this reform the defendant provoked in this way must countersue for trespass. Doing so may result in a desirable sum in damages being awarded. But, apart from the apparently adequate sum, on the suit of the plaintiff the law puts him in the right in spite of his wrongdoings and, on the countersuit of the defendant, the law holds the opposite. This is an inelegant and frankly ridiculous outcome since the actual findings reached in a court of law are supposed to be taken as the final statement of the parties' rights, obligations and blame. The practice of countersuit in such a context is not an inherent feature of the law but it is a necessary band-aid fix in the absence of an adequate law.

\section{B Moral Justifiability of Some Trespasses}

A number of points have been raised in this article, above, with respect to the moral justifiability of some trespasses. A few further points should now be made. It is morally correct that self-defence should be a complete defence. Blay has taken this further and has argued that the principle applies equally '...where a plaintiff causes a defendant to lose his self-control and to react in the heat of passion.... ${ }^{50}$ But that assumes all provocation is intentional, whereas provocation can be accidental or the behaviour may even be well intentioned, though misunderstood. Furthermore, to compare thoughtless aggression with a necessary response to danger is incorrect, and, yet again,

\footnotetext{
${ }^{49}$ Although in itself that is a trespass on which the defendant can counter-sue we shall disregard that possibility and concentrate on improving the concepts with which the law formed.

${ }^{50}$ Blay, above n 13, 156.
} 
self-defence can be undertaken with a cool head and in that case would not resemble a provoked response at all. But the defence of self-defence does apply in provocative situations. Blay is correct in recognising that the provoked response is sometimes unavoidable and reasonable, so that there is a point of overlap where trespass should be justifiable. ${ }^{51}$

\section{Vigilantism}

Slatter J stated in Wilson that:

The law should obviously discourage people from provoking others in ways that might cause them to lose control. This objective must be balanced against the competing objective of discouraging persons from responding to provocation with criminal acts. ${ }^{52}$

In my view, this is a circular argument. If an act is criminal then the law has, by declaring it criminal, already established sanctions against it. If his Honour meant to refer not to technical criminality, but to the ethical principles that the law seeks to embody, then in the end he was only referring to self-help remedies that go to the extent of unreasonableness and foul play. If an act is not unreasonable, then the law should not forbid it, except to soothe the sensibilities of genteel fellows, and to avoid encouraging people to push the envelope to the detriment of others around them. His Honour indicated that matters should be directed to police or else sued on, rather than dealt with through vigilantism. Vigilantism is a real concern in North America, but far less so in most developed countries such as Australia. On the usual meaning of 'vigilantism', a vigilante response is a delayed response as it has to be organised through a network of communication or by discussion of some sort. Such a delay is prima facie evidence of malice afore-thought, the mens rea of a crime, and existing criminal authorities on provocation require directness or immediacy to distinguish a provoked response from an original act. Even if that requirement were liberalised so that the provoked person might smoulder for a while before lashing out in rage, provocation can only be pleaded by the person provoked, not by a group of friends and relatives. Therefore a change in tort law regarding provocation is not going to encourage vigilantism. Where a provocative act results not in automatism but in a response in the interests of justice, there is a question as to whether the defendant was acting in the defence of others and would therefore be exonerated. The only concern is whether the defendant has gone too far.

\footnotetext{
${ }^{51}$ Ibid?

${ }^{52}$ Wilson v Bobbie (2006) ABQB 22, [31].
} 
Blay has also made the point that maintaining the current law does not prevent self help. When reacting to provocation in the heat of the moment, a defendant simply cannot, while reacting, stop and think about legal consequences. ${ }^{53}$ It is well recognised in science and in law that human nature includes a capacity to lose control, to stop thinking and to act reflexively. As discussed in relation to Scott $v$ Shepherd above, when experiencing the fight or flight response, a person is no more morally in the wrong in relation to the provocateur plaintiff than an unmarried person is to be criticised for falling in love at an inconvenient juncture.

Vigilantism also has its merits when an offender is caught in the act and dealt with in a fair and sensible manner. When police fail to intervene as requested, while a harmful or morally repulsive act is in progress or is likely to be repeated, ordinary citizens are in fact acting positively in the interests of law and order by taking matters into their own hands. The Tasmanian case of Downham v Bellette ${ }^{54}$ is raised by Blay as an example of just how bad social behaviour can get, and how little the law of torts will permit the victims to do in defence of themselves and their own. As part of a neighbourhood dispute, the plaintiff took to defecating on the driveway of one defendant. He was caught one night doing so while armed with a rifle. He was held under citizens' arrest by the defendants and beaten. The police were called but eventually instructed the defendants to release the plaintiff. The plaintiff succeeded in suing for assault, battery and false imprisonment. Underwood J held that 'although the plaintiff's conduct was reprehensible it did not justify the assault and subsequent period of false imprisonment' ${ }^{55} \mathrm{He}$ found that 'defecating on the first defendant's driveway ... was the immediate and precipitating cause of the assault and false imprisonment'. ${ }^{56}$ It is relevant to ask whether such disapproval exists in dominant social values or only in the abstractions of the law and the philosophical views of those most deeply opposed to violence per se. This case stands as a good example of the very worst performance of the justice system, such as would provoke the ire of any common decent person.

\section{CONCLUSION}

This article has shown that the law of trespass to the person as it stands requires a level of behaviour that is uncommon and unnatural, albeit high

\footnotetext{
${ }^{53}$ Blay, above n 13, 155.

${ }^{54}$ (1986) Aust Tort Reports 80-038.

${ }^{55}$ Downham v Bellette (1986) Aust Tort Reports, 67,827.

${ }^{56}$ Downham v Bellette (1986) Aust Tort Reports, 68,830.
} 
minded. It is shown here that the law can be changed to reflect more accurately the best of actual human nature, rather than an ideal of what human nature can become. Existing law has been analysed and it has been found to deal inadequately when compared with common knowledge of interpersonal conflict. While there is authority in New Zealand for the recognition of provocation in some cases of trespass, the Victorian Supreme Court has ruled it out on grounds of precedent. The notion of a victim's fundamental right not to be touched or threatened in an unwelcome way as a basis for ignoring provocation has been shown to be unrealistic and inconsistent with contributory negligence in negligence law. An argument of implied consent to a trespass has also been put on the basis of a Canadian authority, and a negative upshot of such a law is identified. Implied consent is also distinguished from the more extreme issue of automatism, which is argued on the basis of long established British law. An issue is identified that if the law were changed in the manner argued for, trespass law would be at odds with the equivalent criminal laws. But a cursory argument is made that a fundamental distinction may already exist in the two concepts of and approaches to provocation, which may justify ignoring what superficially seems like an inelegant contradiction. Policy arguments are then put to give practical reasons for changing the law. Those reasons are bullying, the inherent moral justifiability of some trespasses, and an argument is put against a judicial objection to the encouragement of vigilantism. 